University of Nebraska - Lincoln

DigitalCommons@University of Nebraska - Lincoln

Faculty Publications from the Harold W. Manter Laboratory of Parasitology

4-1946

\title{
Morphology of a New Species of Bat Cestode, Hymenolepis roudabushi, and a Note on Hymenolepis christensoni Macy
}

\author{
Ralph W. Macy \\ Reed College \\ Robert L. Rausch \\ University of Washington, rausch@uw.edu
}

Follow this and additional works at: https://digitalcommons.unl.edu/parasitologyfacpubs

Part of the Parasitology Commons

\begin{abstract}
Macy, Ralph W. and Rausch, Robert L., "Morphology of a New Species of Bat Cestode, Hymenolepis roudabushi, and a Note on Hymenolepis christensoni Macy" (1946). Faculty Publications from the Harold W. Manter Laboratory of Parasitology. 379.

https://digitalcommons.unl.edu/parasitologyfacpubs/379
\end{abstract}

This Article is brought to you for free and open access by the Parasitology, Harold W. Manter Laboratory of at DigitalCommons@University of Nebraska - Lincoln. It has been accepted for inclusion in Faculty Publications from the Harold W. Manter Laboratory of Parasitology by an authorized administrator of DigitalCommons@University of Nebraska - Lincoln. 


\section{MORPHOLOGY OF A NEW SPECIES OF BAT CESTODE, HYMENOLEPIS ROUDABUSHI, AND A NOTE ON HYMENOLEPIS CHRISTENSONI MACY}

RALPH W. MACY ${ }^{1}$ AND RoBert L. RaUSCH ${ }^{2}$

Examination of material of a species of Hymenolepis collected by one of us (R. R.) from several species of bats taken near Marysville, Ohio, revealed that it was new. A series of specimens of the same species was collected in 1942 at Ames, Iowa, by Dr. Robert Roudabush. A description of the new species follows:

$$
\text { Hymenolepis roudabushi } \mathrm{n} \text {. sp. }
$$

Specific diagnosis: Hymenolepis: Strobila $40-70 \mathrm{~mm}$ long by a maximum width of about $1.5 \mathrm{~mm}$ toward the posterior end. Unlike the other North American species from bats, $H$. christensoni, the strobila is serrate and this clearly is not due to the amount of contraction. Scolex $0.26-0.31 \mathrm{~mm}$ wide, with suckers $0.07-0.08 \mathrm{~mm}$ in diameter, and a crown of from $41-48$ hooks each measuring from $0.38-0.43 \mathrm{~mm}$ in length. Genital pores unilateral, slightly anterior to the middle of each proglottid.

Testes $0.11-0.18 \mathrm{~mm}$ in diameter, with one poral and two antiporal in position; arranged in a transverse field instead of a triangular position as in some species. External seminal vesicle about $0.25 \mathrm{~mm}$ long by $0.05 \mathrm{~mm}$ wide; reaching inward past the longitudinal excretory canal, a point of difference compared with some other species. Internal seminal vesicle paralleling the position of the poral testis and measuring from 0.15 to 0.18 $\mathrm{mm}$ long by $0.10 \mathrm{~mm}$ wide. Cirrus often slightly protruding from the genital pore; aspinose.

Ovary narrow, not appreciably lobed; about $0.3 \mathrm{~mm}$ long by about $0.04 \mathrm{~mm}$ wide; placed midway between the longitudinal excretory canals. Vitellarium directly posterior to the ovary; about $0.06 \mathrm{~mm}$ in diameter. Seminal receptable prominent, about $0.4 \mathrm{~mm}$ long; conspicuous and retortshaped in gravid proglottids. Eggs $0.025-0.030 \mathrm{~mm}$ in size.

Host: Eptesicus fuscus (Beauvois); also occurs in Nycticeius humeralis and Lasionycteris noctivagans.

Location: Small intestine.

Locality: Ames, Iowa, and Marysville, Ohio.

Type specimens: In U. S. Nat. Mus. Helm. Collection; also paratypes in authors' collections.

The new species differs from two bat cestodes in that it has the crown of hooks, unlike $H$. moniezi Parona and $H$. grisea Van Beneden; it has the

${ }^{1}$ Department of Biology, Reed College, Portland, Oregon.

2 Department of Bacteriology and Public Health, School of Veterinary Medicine, Michigan State College, East Lansing. 

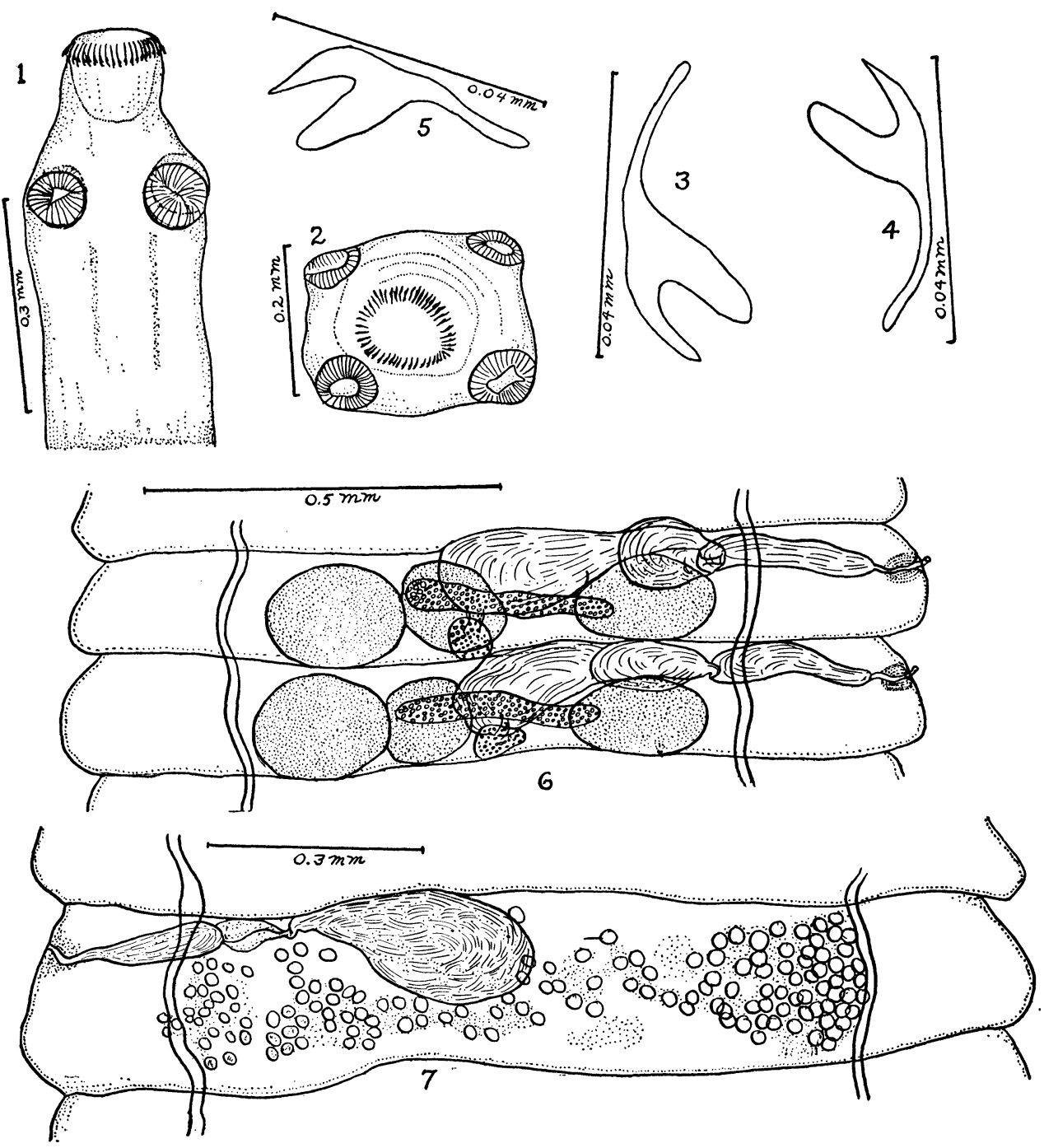

Explanation of Plate

Drawings made to scale with the aid of the camera lucida FIG. 1. Hymenolepis roudabushi, scolex.

Fig. 2. H. roudabushi, scolex, anterior aspect to show hooks.

Fig. 3. H. roudabushi, rostellar hook.

Fig. 4. H. roudabushi, another hook.

FIG. 5. H. christensoni Macy, rostellar hook.

Fig. 6. H. roudabushi, mature proglottids.

Fig. 7. H. roudabushi, gravid proglottid. 
testes in a transverse field, thus differing from $H$. acuta (Rudolphi), $H$. kerivoulae Hübscher, and $H$. sandgroundi Baer, all of which have the testes disposed in a triangular arrangement; it has from 41 to 48 hooks, in this respect clearly different from $H$. chiropterophila Vigueras and $H$. balsaci Joyeux and Baer which have 32 to 34 hooks and 30 hooks respectively; finally the margins of the strobila of $H$. roudabushi are serrate in contrast to those of $H$. christensoni Macy which are not serrate.

The other species of Hymenolepis from North American bats, $H$. christensoni, was originally described from preserved material collected several years before from the little brown bat, Myotis lucifugus, at St. Paul, Minnesota. Dissection by one of us (R. M.) of several hundred Eptesicus fuscus from Minnesota failed to yield any tapeworms other than a few immature Hymenolepis. Examination of several Myotis lucifugus and a larger series of Myotis keenii septentrionalis at the University of Minnesota Biological Station at Lake Itasca in northern Minnesota, August 10-18, 1940, disclosed a considerable number of $H$. christensoni in the intestines. Additional data collected from this material better indicates the extent of variability in this cestode. Particular mention should be made of the length of the hooks which originally was given as $0.033 \mathrm{~mm}$; the measurement should now be stated as 0.033 to $0.038 \mathrm{~mm}$; also the number of hooks has been determined to range from 35 to 41 , whereas in the earlier publication it was given as 35. An additional drawing of a typical hook has been made.

\section{BIBLIOGRAPHY}

Baer, J. G. 1938. Contribution a l'etude de la fauna helminthologique africaine. Rev. Suiss. Zool. 40(3): 31-84.

Hübscher, H. 1937. Notes helminthologiques. Rev. Suiss. Zool. 44(32) : 459-482.

Hughes, R. C. 1941. A key to the species of tapeworms in Hymenolepis. Trans. Amer. Micro. Soc. $60(3): 377-414$.

Joyeux, Ch., and Baer, J. G. 1934. Sur quelques cestodes de France. Arch. Mus. Hist. Nat. (Paris) $11: 157-171$.

Macy, R. W. 1931. A key to the species of Hymenolepis found in bats and the description of a new species, H. christensoni, from Myotis lucifugus. Trans. Amer. Micro. Soc. 50(4): 344-346.

Parona, C. 1893. Hymenolepis moniezi, n. sp., parasita del Pteropus medius, ed. H. acuta (Taenia acuta Rud.) del pipistrelli nosttrali. Atti soc. Ligust. sci. nat. Genova. 4: 202206.

Rudolphi, C. A. 1819. Entozorum synopsis. Berolini. 1-811.

Van Beneden, J. P. 1873. Les parasites des chauves-souris de Belgique. 40.

Vigueras, I. Perez. 1941. Nota sobre Hymenolepis chiropterophila n. sp. y clava para la determinacion de Hymenolepis de Chiroptera. La Revista "Universidad de la Habana," No. 36-37, May-August, pp. 152-163.

von Linstow, O. 1903. Drei neue Taenien aus Ceylon. Centralbl. f. Bakt. etc., Jena. Abt. 1. Orig. 33(7): 532-533. 